\title{
骨材の乾燥収縮ひずみの評価指標に関する研究 STUDY ON EVALUATION INDEX OF DRYING SHRINKAGE STRAIN OF AGGREGATE
}

\author{
寺西浩司*
}

Kohii TERANISHI

\begin{abstract}
In this study, the investigation to find out the evaluation index of drying shrinkage strain of aggregate was carried out. The following findings were obtained as the results. (1) Air-dried moisture content and specific surface area of fine and coarse aggregates, direct measurements of drying shrinkage strain of coarse aggregate etc. correlate highly with the drying shrinkage strain of law stone of aggregate. Therefore, these values can be used as the evaluation index of drying shrinkage strain of aggregate. (2) Some aggregates not corresponding well to drying shrinkage of aggregate are invariably to be found in case of all evaluation indexes. Consequently this fact should be taken into consideration in estimating the drying shrinkage strain of aggregate. (3) The drying shrinkage strain of aggregate has a direct effect on that of concrete.
\end{abstract}

\author{
Keywords : Composite theory, X-ray diffraction, Rock type, Limestone, Specific surface area, \\ Moisture content \\ 複合理論，X線回折，岩種，石灰岩，比表面積，含水率
}

\section{1.はじめに}

コンクリートの収縮ひび割れに関しては、日本建築学会「JASS 5」の2009年版に、長期および超長期供用級に区分されるコンクリー トの乾燥収縮率の上限值 $\left(8 \times 10^{-4}\right)$ が記載された。また、このこと が契機となって、コンクリートの乾燥収縮に対する関心が高まり、 最近、レディーミクストコンクリート工場に対する乾燥収縮ひずみ の実態調查や収縮低減対策の検討が活発に行われている。

全国生コンクリート工業組合連合会の平成 $21 \sim 22$ 年度の調查結 果1)によると、全国のレディーミクストコンクリート工場のうちの 約1割の工場において、乾燥収縮ひずみがJASS 5 の上限值を超えてい た。一方で、レディーミクストコンクリート工場で採用可能な効果 的な収縮低減対策は、実質的に、コンクリートの乾燥収縮ひずみを 小さくできる骨材の使用之、収縮低減剤や膨張材などの収縮低減材 料の使用の2種類にほぼ限定されるものと考えられる。特に、骨材に 関しては、古くから、石灰石骨材を用いた場合にコンクリートの乾 燥収縮ひずみが小さくなることが経験的に知られており2)、最近、 収縮低減効果を期待してこの種の骨材が選択的に使用される事例が 多くなっている。

さらに、このことに関連して、骨材の性質がコンクリートの乾燥
収縮ひずみに大きな影響を及ぼすとの認識も一般に定着してきてお り、乾燥収縮ひずみに対する石灰岩以外の骨材の影響を調べた結果 も筆者ら ${ }^{3)}$ や他の研究者 ${ }^{4)}$,5) から報告されている。そして、収縮低減 効果の高い骨材は石灰岩だけに限らないが、そのような骨材の岩種 のみによる識別は困難なことが明らかにされつつある6)。これらの ことを踏まえると、乾燥収縮を考慮して合理的に骨材を選定するた めには、個々の骨材の乾燥収縮ひずみを直接的に評価する手法を確 立することが重要と考えられる。

一方で、コンクリートの乾燥収縮ひずみは調合によっても変化す る。したがって、レディーミクストコンクリート工場で1つの調合の 乾燥収縮ひずみを確認したとしても、それは、工場で標準化されて いる全ての調合の乾燥収縮ひずみが小さいことを担保したことには ならない。さらに、コンクリートの乾燥収縮ひず夕は使用骨材の品 質の変動によっても日々変動するものと考えられる。しかし、これ らのことを全てコンクリートの乾燥収縮試験により確認すること は、レディーミクストコンクリート工場にとって、費用その他の面 から不可能に近い。この点に関して、筆者らは、これまでに、複合 理論に基づくコンクリートの乾燥収縮予測式を提案している7。 細・粗骨材の乾燥収縮ひずみの值が得られれば、この予測式によ 
り、それらの骨材を用いたあらゆる調合のコンクリートの乾燥収縮 ひずみを推定することができる。

なお、骨材の乾燥収縮ひずみを調べる手段としては、砕石・砕砂 の場合、単純には、骨材原石からコアを採取してその乾燥収縮ひず みを測定するという方法が考えられる。しかし、この方法は実施に 手間が掛かるため、レディーミクストコンクリート工場での受入れ 検査や骨材製造工場での品質管理試験などの手段には適さない。一 方で、最近、骨材の乾燥収縮ひずみをより簡便に評価することを目 的とした研究が多数報告されているが8) 13)、現時点では、標準的な 試験・検查方法が確立されるまでには至っていない。

以上の背景から、本研究では、種々の岩種の骨材を試料とし、骨 材に関する様々な特性值や試験值と骨材の乾燥収縮ひずみの関係を 調べた。そして、その結果を踏まえ、骨材の乾燥収縮ひずみの評価 指標を見出すための検討を行った。

\section{2. 実験概要}

\section{1 試料とした骨材}

本実験では、表1に示すような、広範な岩種の細・粗骨材を試料と した。その際、粗骨材は、砕石2005を中心に収集したが、川砂利や 山砂利も試料に加えた。また、可能な場合は、粗骨材と同一の工場 から砕砂も同時に入手したが、入手できない場合は、スクリーニン グスなどを入手するか、または、粗骨材をジョークラッシャで破砕 し、それらを粒度調整して細骨材とした。

\section{2 試験項目および試験方法}

図1に、本研究で想定したコンクリートの乾燥収縮ひずみの推定つ ローと各試験の位置付けを示寸。同図からわかるように、本研究で は、より本質的な推定方法を構築するために、コンクリートの乾燥 収縮ひずみを骨材に関する特性值や試験值（骨材の乾燥収縮評価指 標）から直接的に推定するのではなく、次の2段階のアプローチによ り推定することを想定した。すなわち、(1)骨材の乾燥収縮評価指標 から、まず、骨材自身の乾燥収縮ひずみを推定する。(2)上記(1)で得 られた結果から、各種調合・セメント種類のコンクリートの乾燥収 縮ひずみを複合理論によりさらに推定する。ここで、乾燥収縮の複 合理論とは、コンクリートをマトリックスセメントペーストと骨材 からなる2相材料と見なし、各相の乾燥収縮ひずみ、弾性係数および 体積比率によってコンクリートの乾燥収縮ひずみを表示しようと考 える理論である14)。

表2に、試験項目および試験方法を示す（図1に示した項目のほか にも試験を行っている）。本実験では、骨材に対する試験項目とし て、先行研究 ${ }^{8)}$ 13) において、コンクリートの乾燥収縮ひずみと密接

\begin{tabular}{|c|c|c|c|c|c|}
\hline 記号 & \multicolumn{2}{|c|}{ 分類 } & 岩種 & 産地 & 種別 \\
\hline HS1 & \multirow{7}{*}{ 堆積岩 } & \multirow{4}{*}{ 砕屑岩 } & 硬質砂岩 & 愛知県 & 砕石, 砕砂 \\
\hline HS2 & & & 硬質砂岩 & 三重県 & 砕石, 砕砂*1 \\
\hline SS & & & 砂岩 & 岐阜県 & 砕石, 砕砂 \\
\hline ST & & & 粘板岩 & 岐阜県 & 砕石, 砕砂 \\
\hline LS1 & & \multirow{3}{*}{$\begin{array}{c}\text { 化学. 生 } \\
\text { 物岩 } \\
\text { (生物岩) }\end{array}$} & 石灰岩 & 三重県 & 砕石, 砕砂 \\
\hline LS2 & & & 石灰岩 & 滋賀県 & 砕石, 砕砂 \\
\hline MS & & & チャート & 岐阜県 & 山砂利, 砕砂*2 \\
\hline AS & \multirow{6}{*}{ 火成岩 } & \multirow{2}{*}{ 火山岩 } & 安山岩 & 福井県 & 砕石, 砕砂 \\
\hline RS & & & 安山岩 & 富山県 & 川砂利, 砕砂*2 \\
\hline DB & & 半深成岩 & 輝緑岩 & 愛知県 & 砕石, 砕砂*1 \\
\hline PT & & \multirow{3}{*}{ 深成岩 } & かんらん岩 & 三重県 & 砕石, 砕砂 \\
\hline $\mathrm{DR}$ & & & 閃緑岩 & 三重県 & 砕石, 砕砂*1 \\
\hline $\mathrm{GN}$ & & & 花こう岩 & 三重県 & 砕石, 砕砂*2 \\
\hline
\end{tabular}

*1 スクリーニングスなどを粒度調整して作製

*2 粗骨材を破砕し、さらに粒度調整して作製

\begin{tabular}{|c|c|c|}
\hline 試験対象 & 試験項目 & 試験方法 \\
\hline \multirow{4}{*}{$\begin{array}{c}\text { 骨材の } \\
\text { 原石コア }\end{array}$} & 乾燥収縮ひずみ & コアの乾燥収縮試験 \\
\hline & 圧縮強度 & \multirow{3}{*}{$\begin{array}{l}\text { コアの圧縮試験 } \\
\text { (静弾性係数は、地盤工学会基準JGS } \\
2521)\end{array}$} \\
\hline & 静弾性係数 & \\
\hline & ポアソン比 & \\
\hline \multirow{6}{*}{$\begin{array}{l}\text { 細骨材, } \\
\text { 粗骨材 }\end{array}$} & 粒度分布 & JIS A 1102 \\
\hline & 密度 & \multirow{2}{*}{ JIS A 1109, JIS A 1110} \\
\hline & 吸水率 & \\
\hline & 気乾含水率 & JIS A 1125 \\
\hline & 安定性 & JIS A 1122 \\
\hline & 比表面積 & 文献8)を参考に実施 \\
\hline \multirow{2}{*}{ 粗骨材 } & 含有する鉱物 & 粉末X線回折分析 \\
\hline & 乾燥収縮ひずみ & 文献9)を参考に実施 \\
\hline 細骨材 & 乾燥収縮ひずみ & モルタル薄片の乾燥収縮ひずみを測定 \\
\hline \multirow{5}{*}{$\begin{array}{l}\text { コンク } \\
\text { リート }\end{array}$} & 乾燥収縮ひずみ & \multirow{2}{*}{ JIS A $1129-3$} \\
\hline & 質量減少率 & \\
\hline & 圧縮強度 & JIS A 1108 \\
\hline & 静弾性係数 & JIS A 1149 \\
\hline & 超音波伝播速度 & 超音波試験器による測定 \\
\hline
\end{tabular}

な関係があると報告されたことのある特性值を主に取り上げた。ま た、このほかに、骨材の乾燥収縮ひずみの評価を目的とした試験も 試行した。さらに、補足的な試験として、上述の2段階のアプローチ ではなく、コンクリートの乾燥収縮ひずみを直接的に推定すること の可能性を探るために、既往の研究10),11) を参考に、コンクリートの 静弾性倸数などを測定した。以下に、本実験で実施した標準的では ない試験の詳細を示す。

\section{（1）原石コアに対する試験}

\section{(1)乾燥収縮試験}

各骨材の製造工場から人頭大の原石塊を 3 個ずつ入手し、それらか らコア $(\phi 35 \times 70 \mathrm{~mm})$ をそれぞれ1本ずつ採取した。そして、それら を3週間吸水させた後に、コアの相対寸る2面にひずみゲージ（長さ



図1 各試験の位置付け 
$30 \mathrm{~mm}$ ）貼付し、恒温恒湿室内（温度 $20^{\circ} \mathrm{C} 、$ 相対湿度 $60 \%$ ) でひずみ を一定値になるまで測定した。

\section{(2)圧縮試験}

上記(1)試験終了後の原石コアに対して圧縮試験を行い、圧縮強 度、静弾性係数およびポアソン比を測定した。その際、横ひずみ は、コアの軸方向に垂直に、ひずみゲージ（長さ $20 \mathrm{~mm}$ ）2枚を新たに 貼り増して測定した。

\section{(2) 細・粗骨材に対する試験}

\section{（a）骨材の特性値を調べるための試験}

\section{(1)気乾含水率試験}

細・粗骨材に対して気乾含水率9)を測定した。この試験では、吸 水させた細・粗骨材を恒温恒湿室内（温度 $20^{\circ} \mathrm{C}$ 、相対湿度 $60 \%$ ）に2 週間放置した後に、JIS A 1125 に準拠して含水率を測定した。その 際、試料は細骨材 $500 \mathrm{~g} 、$ 粗骨材 $5 \mathrm{~kg}$ とし、試験は1回のみとした。

\section{(2)比表面積試験}

今本らの実験 ${ }^{8}$ に倣い、相対湿度 $32.5 \%$ の環境下での、絶乾状態と した細・粗骨材の水蒸気吸着量を測定した。そして、BET法（一点 法）により、次式15)を用いて骨材の内部空隙の比表面積を計算し た。

$$
S=(1-0.325) v \times \frac{6.023 \times 10^{23}}{18} \times 10.8 \times 10^{-20}
$$

ここに、 $S$ : 骨材の比表面積 $\left(\mathrm{m}^{2} / \mathrm{g}\right), v$ : 水蒸気吸着量 $(\mathrm{cc} / \mathrm{g})$ 。

\section{(3)粉末X線回折分析}

粗骨材を粉末状にした試料に対して粉末X線回折分析を行い, 各骨 材の含有する鉱物を同定した。その際、測定は、X線CuK $\alpha / 40 \mathrm{kV} /$ $30 \mathrm{~mA}$ 、計測時間 $2 \mathrm{deg} / \mathrm{min}$ 、測定範囲 $2 \theta=5 \sim 60^{\circ}$ 、サンプリング幅 $0.02 \operatorname{deg} の$ 条件下で行った。

\section{(b) 骨材の乾燥収縮ひずみの評価を目的とした試験 \\ (1)粗骨材の乾燥収縮試験}

田中らの実験9)を参考にして、粗骨材の乾燥収縮ひずみの直接的 な測定を試みた。この試験では、まず、粗骨材表面の一部を削って 平滑にし、その面にひずみゲージ（長さ $2 \mathrm{~mm} ）$ を貼付して防水処理を 行った。そして、その粗骨材を 2 週間吸水させた後に恒温恒湿室内 （温度 $20^{\circ} \mathrm{C}$ 、相対湿度 $60 \%$ ）に存置し、ひずみを経時的に測定した。 なお、試料は各ケースにつき5個とした。

\section{(2)モルタル薄片の乾燥収縮試験}

試料とした各細骨材を用いて薄片状のモルタル供試体（長さ $160 \times$ 幅 $40 \times$ 厚さ $5 \mathrm{~mm}$ ）を作製し、その乾燥収縮ひずみを測定して、細骨材 の乾燥収縮ひずみを間接的に評価した。表3にモルタルの調合を示 す。供試体は材齢7日まで標準水中養生し、その後、ひずみゲージ

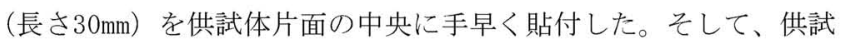
体を恒温恒湿室（温度 $20^{\circ} \mathrm{C}$ 、相対湿度 $60 \%$ ） に存置し、ひずみを経時 的に測定した。なお、供試体は各ケースにつき3枚とした。

\section{（3）コンクリートに対する試験}

\section{(1)乾燥収縮試験}

コンクリートの使用骨材を、同一工場の細・粗骨材をセットとし て変化させて乾燥収縮試験を行った。調合は、HS1のケースを基準と して表4に示すように定めた。また、他のケースでは、空気量は、コ ンクリートの乾燥収縮ひずタに対する影響が小さい16)ことから調整 せず（測定值は0.6 6. 4\%の範囲にあった）、スランプも同様に調整
表3 モルタルの調合

\begin{tabular}{c|c|c|c|c}
\hline \multirow{2}{*}{$\begin{array}{c}\text { 水セメ } \\
\text { マ } \begin{array}{c}\text { ト } \\
(\%)\end{array}\end{array}$} & \multirow{2}{*}{$\begin{array}{c}\text { 砂セメ } \\
\text { ント比 }\end{array}$} & \multicolumn{3}{|c}{ 絶対容積 $\left(l / \mathrm{m}^{3}\right)$} \\
\cline { 3 - 5 } & 水 & セメント & 細骨材 \\
\hline 50 & 3.59 & 256 & 162 & 582 \\
\hline
\end{tabular}

[使用材料］セメント：普通ポルトランドセメント (密度 $3.16 \mathrm{~g} / \mathrm{cm}^{3}$ )

表4 コンクリートの調合（基準ケース：HS1

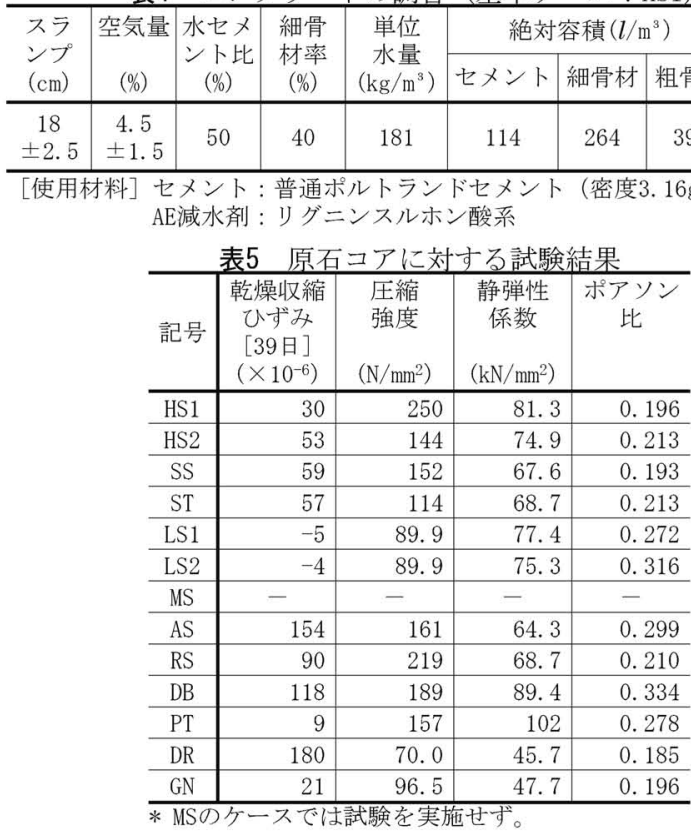

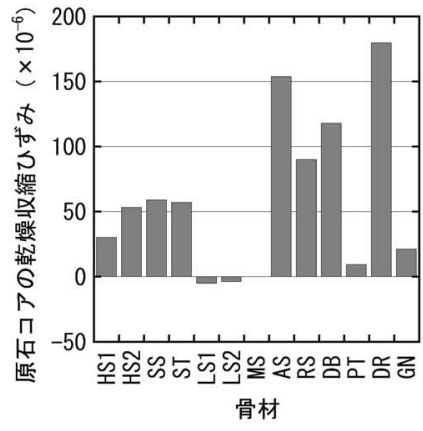

図2 原石コアの乾燥収縮ひずタ

しなかった（試験值は2〜 $20 \mathrm{~cm}$ の範囲にあり、いずれのケースにおい ても、スランプ試験後のコンクリートの状況に材料分離は見られな かった）。なお、供試体は $10 \times 10 \times 40 \mathrm{~cm}$ とし、標準水中養生期間は 7 日間、乾燥条件は温度 $20^{\circ} \mathrm{C}$ 、相対湿度 $60 \%$ とした。

\section{2)圧縮試験・超音波伝播速度の測定}

上記(1)と同一のコンクリートに対して圧縮試験を行い、圧縮強度

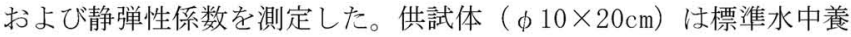
生とし、試験材齢は28日とした。また、圧縮試験の直前に、超音波 測定器（使用周波数20 $500 \mathrm{kHz}$ ）を用いて供試体の軸方向の超音波 伝播速度を測定した。

\section{3．原石コアに対する試験結果}

\section{1 原石コアの乾燥収縮ひずみ}

表5に、原石コアに対する試験結果の一覧を示す。また、図2に、 ほぼ一定值に収束した時点での原石コアの乾燥収縮ひずみを示す （乾燥期間39日）。同図から、石灰岩LS1およびLS2の乾燥収縮ひず みが非常に小さいことがわかる。 
表6 粉末X線回折で同定された各骨材の含有する鉱物

\begin{tabular}{|c|c|c|c|c|c|c|c|c|c|c|c|c|c|c|c|}
\hline \multirow{2}{*}{\multicolumn{2}{|c|}{ ケイ酸塩鉱物の構造群 }} & \multirow[t]{2}{*}{ 鉱物名 } & \multicolumn{4}{|c|}{ 砕屑岩 } & \multicolumn{3}{|c|}{ 生物岩 } & \multicolumn{2}{|c|}{ 火山岩 } & \multirow{2}{*}{$\begin{array}{c}\text { 半深 } \\
\text { 成岩 } \\
\mathrm{DB} \\
\end{array}$} & \multicolumn{3}{|c|}{ 深成岩 } \\
\hline & & & HS1 & HS2 & SS & ST & LS1 & LS2 & MS & AS & RS & & $\mathrm{PT}$ & $\mathrm{DR}$ & GN \\
\hline \multirow{5}{*}{$\begin{array}{l}\text { テクト } \\
\text { ケイ酸塩 }\end{array}$} & シリカ鉱物 & 石英 & 0 & 0 & 0 & 0 & 0 & 0 & 0 & 0 & 0 & 0 & 0 & 0 & $\mathrm{O}$ \\
\hline & \multirow{4}{*}{ 長石 } & 曹長石 & 0 & 0 & & & & & & 0 & 0 & 0 & 0 & 0 & 0 \\
\hline & & 中性長石 & & & & & & & & 0 & & & & & \\
\hline & & 扊長石 & & & & & & & & & & & & & 0 \\
\hline & & 正長石 & & & & & & & & & 0 & & & & \\
\hline \multirow{5}{*}{$\begin{array}{c}\text { フィロ } \\
\text { ケイ酸塩 }\end{array}$} & \multirow{3}{*}{ 雲母族 } & 白雲母 & & & 0 & 0 & & & & & 0 & & & & \\
\hline & & 黒雲母 & 0 & 0 & & & & & & & & & 0 & & 0 \\
\hline & & 金雲母 & 0 & & & & & & & & & & & & \\
\hline & 緑泥石 & クリノクロア & & & 0 & & & & & 0 & 0 & 0 & & 0 & 0 \\
\hline & 粘土鉱物 & イライト & & & & & & & & 0 & & & & & \\
\hline \multirow{2}{*}{$\begin{array}{c}\text { イノ } \\
\text { ケイ酸塩 } \\
\end{array}$} & 輝石族 & 透輝石 & & & & & & & & & & 0 & & & \\
\hline & 角閃石族 & クロス閃石 & & & & & & & & & & & & 0 & \\
\hline \multirow{2}{*}{\multicolumn{2}{|c|}{ ケイ酸塩以外の造岩鉱物 }} & 方解石 & & & & & 0 & 0 & & & & 0 & & & \\
\hline & & 苦灰石 & & & & & 0 & & & & & & & & \\
\hline
\end{tabular}

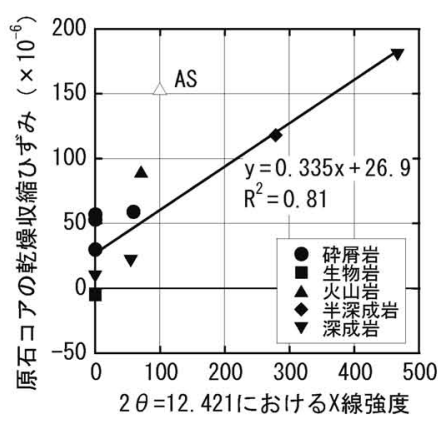

図3原石コアの乾燥収縮ひずみと クリノクロア含有量の関係

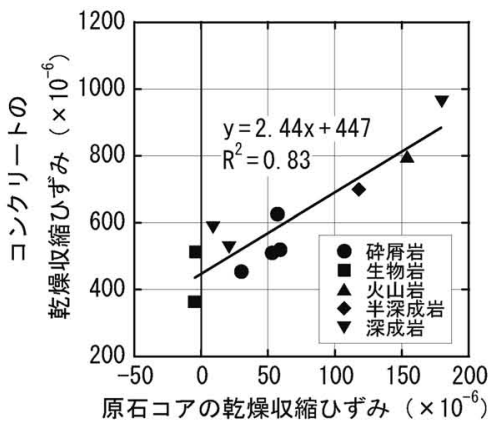

図4 コンクリートの乾燥収縮ひずみ (乾燥期間182日)

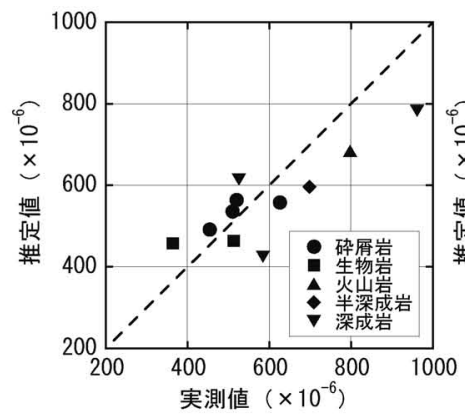

(a) $E_{s}$ およ゙ $E_{g}$ に原石コアの 試験值を入力した場合

図5 コンクリートと原石コアの 乾燥収縮ひずみの関係

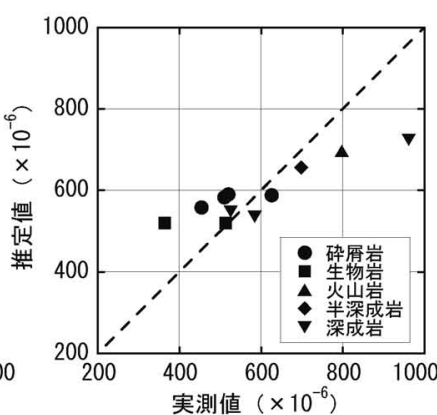

(b) $E_{s}$ およ゙ $E_{g}$ に一定值を 入力した場合

図6式(2)によるコンクリートの乾燥収縮ひずみ の推定值と実測值の関係

べた。図3に、その結果と原石コアの乾燥収縮ひずみの関係を示す

（クリノクロアが同定されなかった骨材のピーク強度は0とした）。 同図によると、クリノクロアのピーク強度が高いほど原石コアの乾 燥収縮ひずみが大きい傾向となっており、このことは、粘土鉣物の 種類が同一の場合、その含有量が多いほど骨材の乾燥収縮ひずみが 大きくなることを示唆している。

なお、図3において、安山岩ASのプロットは回帰直線から外れた位 置にあるが、その原因としては、ASが、粘土鉱物として、クリノク ロアのほかにイライトも含んでいることが考えられる。

\section{4.コンクリートに対する試験結果}

表7に、各骨材を用いたコンクリートに対する試験結果の一覧を示 す。また、図4に、コンクリートの乾燥収縮ひずみを示す（乾燥期間 182日）。同図によると、これまでの多数の報告と同様に、石灰石骨 材を用いたコンクリート（LS1およびLS2）の乾燥収縮ひずみが小さ
くなっている。

\section{1 コンクリートと原石コアの乾燥収縮ひずみの関係}

図5に、コンクリートと原石コアの乾燥収縮ひずみの関倸を示す。 同図によると、両者の間に高い相関が見られ、このことから、骨材 の乾燥収縮ひずみは、コンクリートの乾燥収縮ひずみに直接的な影 響を及ぼすことがわかる。

\section{2 コンクリートの乾燥収縮ひずみの予測式による推定}

図6に、筆者らが過去に提案した、複合理論に基づく乾燥収縮予測 式7)(日本建築学会「ひび割れ制御指針」の付録2 ${ }^{17)}$ に掲載されてい る式）によるコンクリートの乾燥収縮ひずみの推定值と実測值の関 係を示す。ここで、推定值は、筆者らの提案式を、JIS乾燥収縮試験 の乾燥期間182日における試駼結果のみを推定する形に特化して表示 した次式により計算した。 
表8 式(2)における定数の值（普通 \begin{tabular}{c|c|c|c|c|c}
\multicolumn{6}{c|}{ ポルトランドセメント場合） } \\
\hline$\alpha$ & $\beta$ & $\lambda$ & $\delta$ & $\gamma$ & $\eta$ \\
\hline
\end{tabular} \begin{tabular}{c|c|c|c|c|c}
$\alpha$ & $\beta$ & $\lambda$ & $\delta$ & $\gamma$ & $\eta$ \\
\hline 0.322 & 4.77 & 86.3 & 54 & 5.9 & 4.2 \\
\hline
\end{tabular}



\begin{tabular}{|c|c|c|c|c|c|c|c|c|c|c|c|c|c|c|}
\hline \multirow{2}{*}{ 記号 } & \multicolumn{2}{|c|}{ 粗粒率 } & \multicolumn{2}{|c|}{$\begin{array}{c}\text { 絶乾密度 } \\
\left(\mathrm{g} / \mathrm{cm}^{3}\right)\end{array}$} & \multicolumn{2}{|c|}{$\begin{array}{c}\text { 吸水率 } \\
(\%)\end{array}$} & \multicolumn{2}{|c|}{$\begin{array}{c}\text { 気乾含水率 } \\
(\%)\end{array}$} & \multicolumn{2}{|c|}{$\begin{array}{c}\text { 損失質量分率 } \\
(\%)\end{array}$} & \multicolumn{2}{|c|}{$\begin{array}{c}\text { 比表面積 } \\
\left(\mathrm{m}^{2} / \mathrm{g}\right)\end{array}$} & \multirow{2}{*}{$\begin{array}{c}\text { 粗骨材 } \\
\text { 乾燥収縮 } \\
\text { ひずみ } \\
{[14 \text { 日 }]} \\
\left(\times 10^{-6}\right) \\
\end{array}$} & \multirow{2}{*}{$\begin{array}{c}\text { モル夕薄片 } \\
\text { 乾燥収縮 } \\
\text { ひずみみ } \\
{[28 \text { 日] }} \\
\left(\times 10^{-6}\right) \\
\end{array}$} \\
\hline & 細骨材 & 粗骨材 & 細骨材 & 粗骨材 & 細骨材 & 粗骨材 & 細骨材 & 粗骨材 & 細骨材 & 粗骨材 & 細骨材 & 粗骨材 & & \\
\hline HS1 & 11 & 70 & 65 & 67 & 92 & 55 & 53 & 0.20 & 2.4 & 4.5 & 58 & 3.47 & 32 & 614 \\
\hline HS2 & 3.49 & 6.80 & 2.58 & 2.68 & 2.25 & 0.66 & 0.45 & 0.30 & 3.8 & 4. 4 & 4.20 & 3.42 & 126 & 632 \\
\hline SS & 3.12 & 6.83 & 2.63 & 67 & 0.91 & 0.37 & 0.32 & 0.15 & 6.1 & 3.9 & 6. & 02 & 47 & 588 \\
\hline ST & 13 & 01 & 2.53 & 68 & 2.88 & 0.74 & 0.71 & 0.33 & 2.7 & 2.3 & 3.9 & .17 & 119 & 711 \\
\hline LS1 & 2.90 & 6.42 & 2.64 & 2.69 & 1.38 & 0.35 & 0.22 & 0.08 & 2.0 & 1.8 & 0.38 & 0.56 & 9 & 393 \\
\hline LS2 & 2.35 & 6.73 & 2.67 & 2.70 & 0.61 & 0.21 & 0.20 & 0.05 & 1.3 & 1.0 & 0.36 & 0.27 & 14 & 526 \\
\hline MS & 3.02 & 7.10 & 2.54 & 2.52 & 1.71 & 1.23 & 0.46 & 0.28 & - & 2.6 & 1. 38 & 2.32 & 57 & 633 \\
\hline AS & 2.38 & 6.66 & 2.62 & 2.62 & 1.24 & 0.83 & 0.44 & 0.30 & - & 2.6 & 3.26 & 2.64 & 135 & 655 \\
\hline RS & - & 6.67 & 2.54 & 2.58 & 1.97 & 1.21 & 0.62 & 0.42 & 1.6 & - & 1. 35 & 2. 88 & 102 & 735 \\
\hline $\mathrm{DB}$ & 3.14 & 6.49 & 2.78 & 2.97 & 2.59 & 0.56 & 0.51 & 0.27 & 1.8 & 1.9 & 4. 81 & 3.80 & 116 & 749 \\
\hline PT & 3.13 & 6.81 & 2.86 & 3.00 & 1.70 & 0.68 & 0.75 & 0.41 & 4.7 & 2.2 & 5.56 & 5.37 & -65 & 728 \\
\hline DR & 2.61 & 6.44 & 2.55 & 2.68 & 3.67 & 1.09 & 1.16 & 0.64 & 3.6 & 12.8 & 6.89 & 5.90 & 178 & 1063 \\
\hline GN & 3.09 & 6.93 & 2.66 & 2.65 & 0.77 & 0.68 & 0.45 & 0.28 & - & 2.7 & 2.67 & 1.96 & 141 & 596 \\
\hline
\end{tabular}

図7 コンクリートの乾燥収縮ひずみと質量減少率の関係

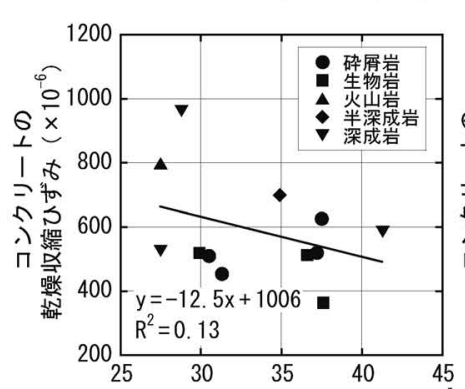

コンクリートの静弾性係数 $\left(\mathrm{kN} / \mathrm{mm}^{2}\right)$

図8 コンクリートの乾燥収縮 ひずみと静弾性係数の関係

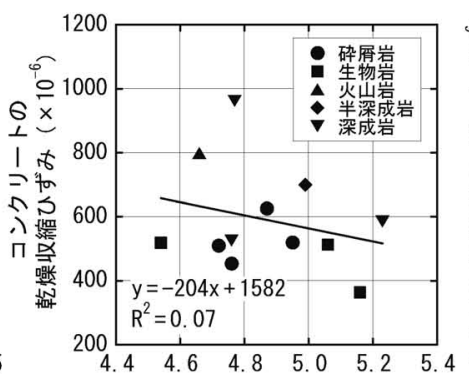

コンクリートの超音波伝播速度 $(\mathrm{km} / \mathrm{s})$

図9 コンクリートの乾燥収縮ひずみ と超音波伝播速度の関係

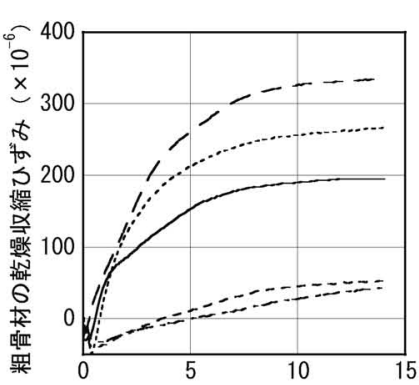

乾燥期間（日）

図10＼cjkstart粗骨材の乾燥収縮ひずみ の測定例（DR）

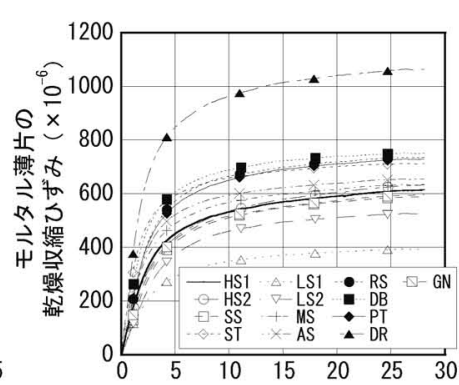

乾燥期間（日）

図11 モルタル薄片の乾燥収縮 ひずみ $\varepsilon_{s c}=\varepsilon_{s p} \frac{1-\left(1-m_{s} n_{s}\right) V_{s}-\left(1-m_{g} n_{g}\right) V_{g}}{n_{c}}$

ここに、

$$
n_{c}=1+\frac{2\left(n_{s}-1\right) V_{s}}{n_{s}+1-\left(n_{s}-1\right)\left(V_{s}+V_{g}\right)}+\frac{2\left(n_{g}-1\right) V_{g}}{n_{g}+1-\left(n_{g}-1\right)\left(V_{s}+V_{g}\right)}
$$

$\varepsilon_{s p}=\frac{182}{2.31(\alpha W / C+\beta)+182}(\lambda W / C+\delta)$

$E_{p}=\frac{100}{W / C} \gamma+\eta$

ここに、 $n_{s}=E_{s} / E_{p}, n_{g}=E_{g} / E_{p}, m_{s}=\varepsilon_{s s} / \varepsilon_{s p}, m_{g}=\varepsilon_{s g} / \varepsilon_{s p}$, $\varepsilon_{s}$ : 乾燥収縮ひずみ $\left(\times 10^{-6}\right), E$ : 弾性倸数 $\left(\mathrm{kN} / \mathrm{mm}^{2}\right), V:$ 骨 材体積比, $W / C$ : 水セメント比 (\%) , $\alpha, \beta, \lambda, \delta, \gamma, \eta$ : セメン 卜の種類に関わる定数（表 8 にる）。

※添字 $c, p, s, g$ 、それぞれコンクリート、セメントペースト、

細骨材、粗骨材を表す。

上式は、細・粗骨材の乾燥収縮ひずみおよび弾性係数の值を入力 する形になっており、図（a）は、これらに原石コアの試験值を入力 した場合である。同図によると、推定值は、実測值より全体的にや や小さくなっているものの、骨材の乾燥収縮ひずみの相違を明確に 反映した值となっている。また、図（b）は、骨材の弾性係数の值が 試験で得られないケースを想定し、これらに、平均的な骨材の值7) として $E_{s}=E_{g}=60\left(\mathrm{kN} / \mathrm{mm}^{2}\right)$ を入力した場合である。この場合、推 定值は、弾性係数に試験值を入力した場合よりやや平均化するが、 全体的な傾向は図（a）の場合とほぼ同様となっている。いずれにし ても、以上のことから、骨材の乾燥収縮ひずみの值が得られれば、
それに基づいて、コンクリートの乾燥収縮ひずみを、同式によりあ る程度の精度で推定できるといえる。

\section{3 コンクリートの乾燥収縮ひずみと質量減少率の関係}

図7に、コンクリートの乾燥収縮ひずみと質量減少率の関係を示 す。同図からわかるように、両者の間には相関が見られ、コンク リートの質量減少率が大きいほど乾燥収縮ひずみが大きくなってい る。すなわち、骨材の違いが、コンクリートの乾燥収縮ひずみと水 分逸散量のいずれに対しても影響を及ぼしている。

なお、図7において、安山岩ASのプロットは、回帰直線からやや外 れた位置にあるが、その理由としては、3.2節に前述したように、AS が、他の骨材とは異なる種類の粘土鉱物を含んでいることが考えら れる。

\section{4 コンクリートの乾燥収縮ひずみと弾性係数の関係}

図8および9に、コンクリートの乾燥収縮ひずみと静弾性係数およ び超音波伝播速度の関係を示す。片平ら ${ }^{10)}$ は、骨材を砕屑岩とそれ 以外の岩種に層別すれば、これらの閒に高い相関が見られると報告 している。しかし、本実験では、そのような結果になっておらず、 コンクリートの静弾性係数やそれに関連する試験值からコンクリー トの乾燥収縮ひずみを推定することは困難と判断される。ただし、 このような結果になったことに対しては、本実験において、コンク リートの空気量を一定に調整しなかったことも影響しているものと 考えられる。

\section{5. 細・粗骨材に対する試験結果}

\section{1 骨材に関する特性値および試験値}

表9に、細・粗骨材に対する試験結果の一覽を示す。また、図10 


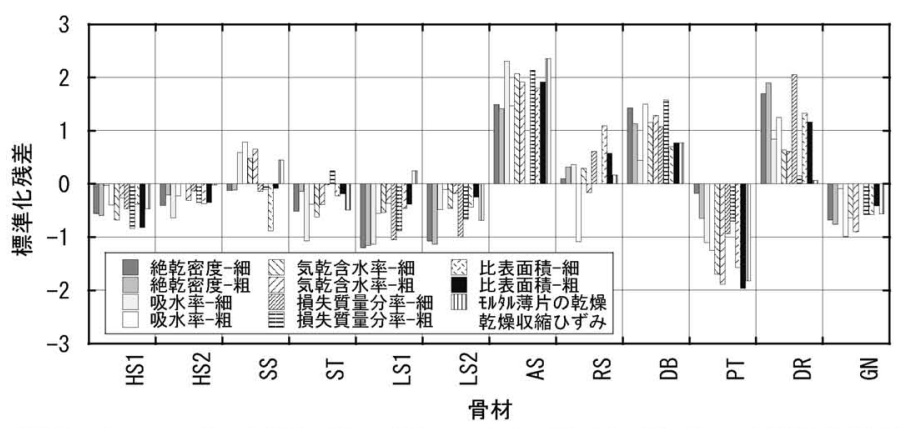

図12 原石コアの乾燥収縮ひずみとの間の回帰分析における標準化残差

に、粗骨材の乾燥收縮試験結果の一例を示す（DRの場合）。図10か らわかるように、5個の試料の測定值には大きなばらつきが見られ、 このことは他のケースでも同様であった。すなわち、骨材粒子間に は乾燥収縮ひずみのかなり大きなばらつきが内在し、その原因とし ては、骨材粒子間の岩質のばらつきが考えられる。また、西岡ら ${ }^{18)}$ は、骨材の乾燥収縮ひずみに異方性が見られると報告しており、こ のこともばらつきの原因となるものと考えられる。なお、図10によ ると、粗骨材の乾燥収縮ひずみは、乾燥期間14日の時点でほぼ一定 值に収束している。

また、表9によると、かんらん岩PTの粗骨材の乾燥収縮ひずみは比 較的大きな負の值となっている。この原因は定かではないが、一つ の可能性としては、かんらん岩中に含まれている繊維状・板状の蛇 紋岩鉱物であるクリソタイルやアンティゴライトの間に入り込んだ 水分が、乾燥開始後も長く骨材中に残留し、乾燥環境下での粗骨材 の膨張変形を促したことなどが考えられる。さらに言えば、図2にお いて、PTの原石コアの乾燥収縮ひずみがかなり小さな值となってい ることも、このような理由によると解釈することが可能である。

図11に、モルタル薄片の乾燥収縮試験結果を示寸（ケースごとの 平均值）。同図によると、乾燥収縮ひずみの測定值は、乾燥期間 28 日の時点でほぼ一定になっている。

\section{2 原石コアの乾燥収縮ひずみと骨材の特性值・試験値の関係}

これまでに示したように、骨材に関する何らかの特性值や試験值 を骨材の乾燥収縮ひずみと関連付けることができれば、その值を指 標として、コンクリートの乾燥収縮ひずみを式（2）などにより推定 することが可能となる。そこで、ここでは、骨材の乾燥収縮ひずみ の評価指標を見出すための検討を行った。具体的には、原石コアの 乾燥収縮ひずみを骨材の真の乾燥収縮ひずみと見なし、この值と骨 材に関する特性值や試験值との間の線形回帰分析を行った。

ただし、事前の予備的な検討として、回帰分析に㧍ける標準化残 差を計算したところ、その絶対值は、図12に示すように、ASおよび PTの場合に、多くの分析ケースで大きな值となり、外れ值の目安で ある2に近いかそれ以上の值となった。すなわち、これら2つの骨材 のデータが相関を著しく低下させる原因となった。そのため、以下 の考察では、これらのデータを特異と見なし、回帰分析の対象から 除いた。また、図中では、AS㧍よびPTのデータを白抜きのプロット で、その他のデータを黒塗りのプロットで表示した。なお、安山岩 ASのデータが特異となったことに対しては、3.2節および4. 3節の考 察においてもこのデータが特異であったことが関係している可能性 がある。また、かんらん岩PTのデータが特異となったことに対して は、5.1節の考察に示したように、この骨材の収縮機構が他の骨材と
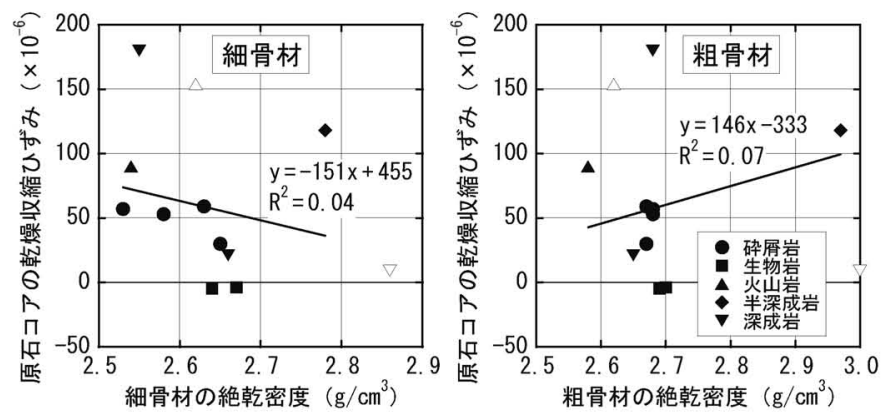

図13 原石コアの乾燥収縮ひずみと骨材の絶乾密度の関係
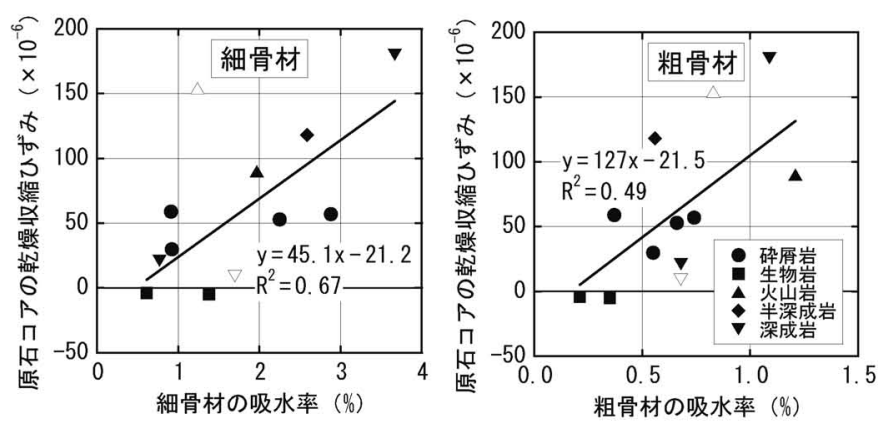

図14 原石コアの乾燥収縮ひずみと骨材の吸水率の関係
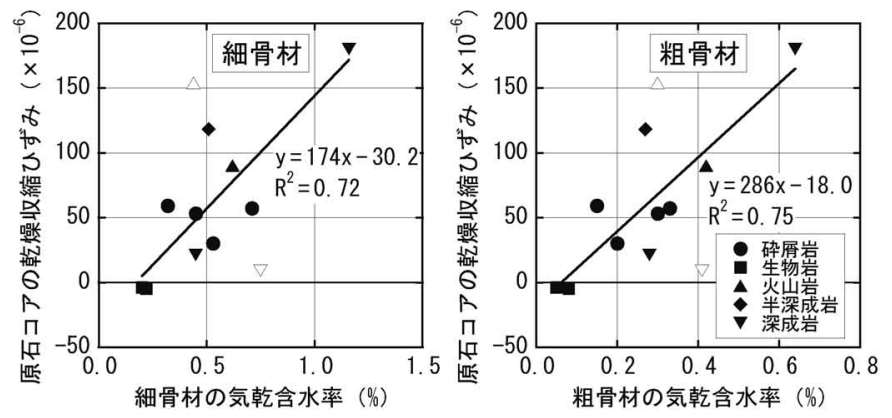

図15 原石コアの乾燥収縮ひずみと骨材の気乾含水率の関係
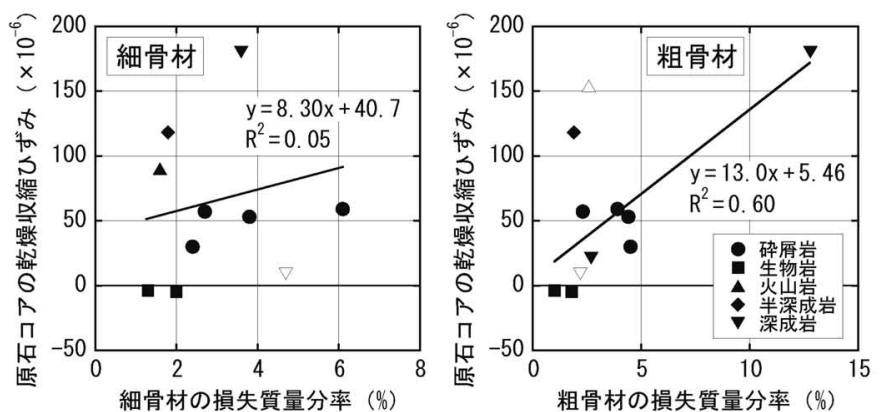

図16 原石コアの乾燥収縮ひずみと骨材の安定性の関係

やや異なると考えられることが関倸している可能性がある。

\section{(1) 骨材の吸水率 $\cdot$ 気乾含水率との関係}

図13〜15に、原石コアの乾燥収縮ひずみと骨材の絶乾密度、吸水 率および気乾含水率の関係を示す。これらの中で、細・粗骨材の吸 水率には、原石コアの乾燥収縮ひずみとの間にある程度の相関が見 られる。しかし、図15によると、細・粗骨材の気乾含水率には、吸 水率よりもさらに高い相関が見られる。また、以上と同様な傾向 は、兵頭ら ${ }^{11)}$ にっても報告されている。

\section{（2）骨材の安定性との関係}

図16に、原石コアの乾燥収縮ひずみと骨材の損失質量分率（安定 性試験の結果）の関倸を示す。同図によると、細骨材の場合、両者 
の間に相関は見られない。一方、粗骨材の場合、寄与率は 0.60 であ り、ASおよびPTのほかにさらに半深成岩の1ケースのデータを除いた

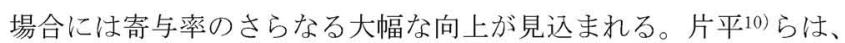
調合一定のコンクリートの乾燥収縮ひずみと骨材の安定性との間に 相関が見られると報告しており、このことを考え合わせても、原石 コアの乾燥収縮ひずみと粗骨材の安定性には関連性があるものと判 断できる。

\section{（3）骨材の比表面積との関係}

図17に、原石コアの乾燥収縮ひずみと骨材の内部空隙の比表面積 の関係を示す。この両者の間に密接な関係があることは小山田ら ${ }^{12)}$ によって報告されており、また、コンクリートの乾燥収縮ひずみと 骨材の比表面積の関連性が高いことも今本ら8)や片平ら ${ }^{10)}$ によって 報告されている。それに対し、本実験では、粗骨材を試料とした場 合に、既往の研究と同様に、両者の間に高い相関が見られた。な お、堀口ら ${ }^{19)}$ は、本実験と一部共通寸る粗骨材試料を用いて同様の 趣旨の実験を行っており、その実験においても、粗骨材の乾燥収縮 ひずみと比表面積の閒に高い相関が見られることが確認されてい る。

\section{（4）粗骨材の乾燥収縮ひずみとの関係}

図18に、原石コアと粗骨材の乾燥収縮ひずみの関倸を示す。同図 によると、両者の值は、ほとんどの骨材においてほぼ一致してい る。すなわち、粗骨材にひずみゲージを貼付して乾燥収縮ひずみを 測定すれば、原石コアに対する場合とほぼ同一の測定結果が得られ るといえる。ただし、中には対応の悪い骨材もあり、本実験の範囲 では、その原因は明らかにならなかった。

\section{（5）モルタル薄片の乾燥収縮ひずみとの関係}

図19に、原石コアとモルタル薄片の乾燥収縮ひずみの関係を示 す。寄与率は0.89であり、両者の相関は高いといえる。したがっ て、使用する細骨材を用いてモルタル薄片を作製し、その乾燥収縮 ひずみを測定すれば、骨材の乾燥収縮ひずみを比較的高い精度で推 定できるものと考えられる。

\section{3 骨材の乾燥収縮評価指標}

表10に、前節の考察で、原石コアの乾燥収縮ひずみとの間に比較 的高い相関が得られた骨材の特性值および試験值を、試験方法の特 徵などと併せて整理して示す。

これらの試験を、レディーミクストコンクリート工場での受入れ 検查や骨材製造工場での品質管理試験として実施することを想定し た場合、比較的簡単に実施可能なのは、表中の(1)気乾含水率試験お よび(2)比表面積試験である。また、直接的に骨材の乾燥収縮ひずみ の測定值が得られるという点で、(3)粗骨材の乾燥収縮試験には高い 精度が期待できる。ただし、いずれの特性值や試験值の場合も、前 述のように、骨材（原石コア）の乾燥収縮ひずみとの対応の悪い骨 材が必ず一部に存在する。また、現時点では、それがどのような骨 材かを特定することも難しい。したがって、骨材の乾燥収縮ひずみ の推定にあたっては、このことに対する配慮が必要となる。

\section{6. まとめ}

本研究では、コンクリートの乾燥収縮を考慮して合理的に骨材を 選定する方法の確立を目的として、骨材に関寸る様々な特性值や試 験值と骨材の乾燥収縮ひずみの関係を調べた。また、その結果を基
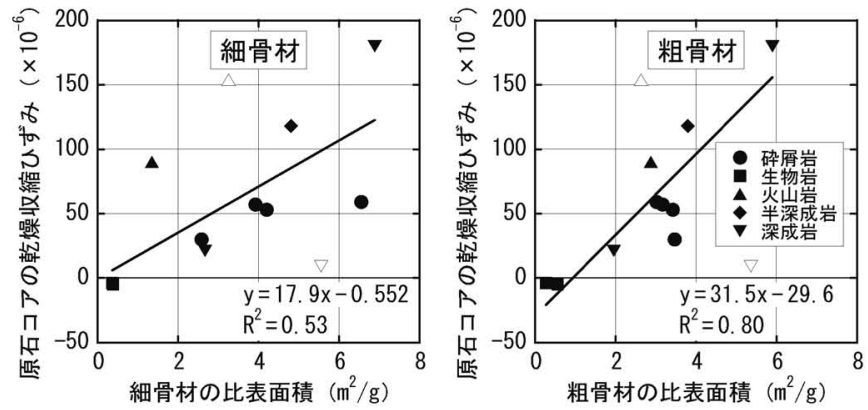

図17原石コアの乾燥収縮ひずタと骨材の比表面積の関係

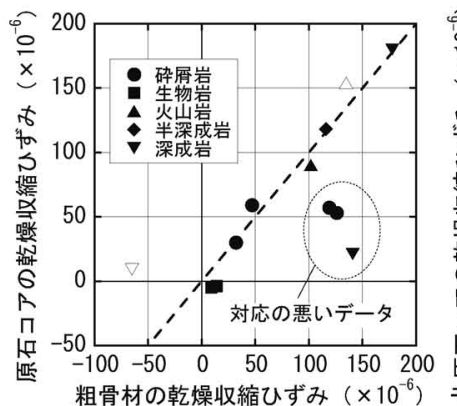

粗骨材の乾燥収縮ひずみ $\left(\times 10^{-6}\right)$

図18＼cjkstart原石コアと粗骨材の乾燥 収縮ひずみの関係

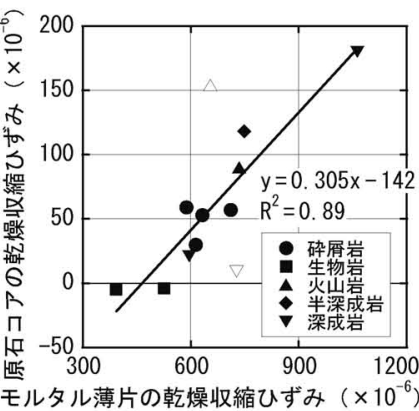

図19 原石コアとモルタル薄片 の乾燥収縮ひずみの関係

\begin{tabular}{|c|c|c|c|c|c|}
\hline \multirow[b]{2}{*}{ 試験方法 } & \multirow[b]{2}{*}{$\begin{array}{l}\text { 対象 } \\
\text { 骨材 }\end{array}$} & \multicolumn{3}{|c|}{ 試験方法の特徵 } & \multirow[b]{2}{*}{$\begin{array}{l}\text { 試験に要 } \\
\text { する期間 }\end{array}$} \\
\hline & & 推定精度* & $\begin{array}{l}\text { 骨材粒子間のば } \\
\text { つさの晾響の } \\
\text { 受けにくささ }\end{array}$ & $\begin{array}{l}\text { 試験実施 } \\
\text { の容易さ }\end{array}$ & \\
\hline \multirow{2}{*}{ (1)気乾含水率試験 } & \begin{tabular}{|l|l} 
細骨材 \\
\end{tabular} & $\triangle(0.72)$ & \multirow{2}{*}{ (C) } & \multirow{2}{*}{ O } & \multirow{2}{*}{$\begin{array}{c}\text { 2週間 } \\
\text { 程度 }\end{array}$} \\
\hline & 粗骨材 & $\triangle(0.75)$ & & & \\
\hline (2)比表面積試験 & 粗骨材 & $\bigcirc(0.80)$ & O & O & $\begin{array}{l}\text { 2週間 } \\
\text { 程度 }\end{array}$ \\
\hline $\begin{array}{l}\text { (3)粗骨材の乾燥収 } \\
\text { 縮試験 }\end{array}$ & 粗骨材 & (a) & $\triangle$ & $\triangle$ & $\begin{array}{c}\text { 4〜6週間 } \\
\text { 程度 }\end{array}$ \\
\hline $\begin{array}{c}\text { (4) モルタル薄片の } \\
\text { 乾燥収縮試験 }\end{array}$ & 細骨材 & (9) $(0.89)$ & O & $\triangle$ & $\begin{array}{l}\text { 4週間 } \\
\text { 程度 }\end{array}$ \\
\hline
\end{tabular}

に、骨材の乾燥収縮ひずみの評価指標を見出すための検討を行っ

た。本研究で得られた知見は、以下の通りである。

(1) 粘土鉱物の含有量が多いほど、骨材の乾燥収縮ひずみが大きい傾 向となる。

(2) 骨材の乾燥収縮ひずみは、コンクリートの乾燥収縮ひずみに直接 的な影響を及ぼす。また、細・粗骨材の乾燥収縮ひずみの值が得 られれば、それに基づいて、複合理論を基盤とした乾燥収縮予測 式により、各種調合のコンクリートの乾燥収縮ひずみをある程度 の精度で推定することが可能である。

(3) 本研究で得られた実験結果からは、コンクリートの弾性係数やそ れに関連する試験值からコンクリートの乾燥収縮ひずみを推定す ることは困難といえる。

(4) 本研究の範囲内では、細・粗骨材の気乾含水率および比表面積、 粗骨材の乾燥収縮ひずみの直接的な測定值、ならびに細骨材を用 いて作製したモルタル薄片供試体の乾燥収縮ひずみと、骨材原石 の乾燥収縮ひずみとの間に高い相関が見られる。したがって、こ れらの骨材に関寸る特性值や試験值は、骨材の乾燥収縮ひずみの 評価指標となり得る。

（5）レディーミクストコンクリート工場での受入れ検查や骨材製造工 場での品質管理試験を想定した場合、上記の中で比較的簡単に実 
施可能なのは、気乾含水率試験および比表面積試験である。ま た、試験実施にやや手間が掛かるものの、測定結果に高い精度が 期待されるのは、粗骨材の乾燥収縮試験である。ただし、これら のいずれの特性值や試験值にも、骨材の乾燥収縮ひずみとの対応 の悪い骨材が必ず一部に存在する。したがって、骨材の乾燥収縮 ひずみの推定にあたっては、このことに対する配慮が必要とな る。

\section{謝辞}

本研究は、コンクリート技術支援機構（ASCoT）「収縮ひび割れ研 究委員会」20),21) への協力を前提として実施したものである。

本研究の実施に際し、森野奎二愛知工業大学名誉教授に粉末X線回 折について、東京理科大学・今本啓一准教授に骨材の比表面積試験 についてそれぞれご教授頂いた。また、東亜開発（株）三重総合試 験センターに実験の一部を実施して頂いた。ここに付記して謝意を 表します。

\section{参考文献}

1）コンクリートエ学協会：コンクリートの収縮問題検討委員会報告書, pp. $13-23,2010.3$

2）セメント協会：耐久性専門委員会ひび割れ分科会報告H-23，pp. 23-36, 1992. 10

3）寺西浩司：コンクリートの乾燥收縮に影響を及ぼす要因一骨材や単位水 量の影響をどのように考えるかー, コンクリート工学, Vol. 46, No. 12, pp. 11-19, 2008. 12

4）立松和彦，荒井正直，岩清水隆，木村芳幹，浦野英男，今本啓一，元木 亮: 関西地域における骨材原石の乾燥収縮および細孔径分布に関する実験 的研究, 日本建築学会構造系論文集, No. 549, pp. 1-6, 2001. 11

5）大野義照, 片岡宏治, 熊野知司, 高見新一, 麓隆行 : 近畿地方の骨材需給 の現況と近畿産骨材を使用したモルタルの乾燥収縮一近畿支部「性能評価 型コンクリートに向けた骨材調查研究委員会」の報告-, コンクリートエ 学, Vol. 50, No. 6, pp. 524-532, 2012.6

6）閑田徽志，百瀬晴基 : 乾燥収縮ひずみに注目した天然骨材選定例，コンク リート工学, Vol. 46, No. 5, pp. 24-29, 2008.5
7）寺西浩司，佐藤嘉昭：複合モデルを基盤としたコンクリートの乾燥収縮予 測式 -3 相モデルへの展開および外的要因の影響の考慮一, 日本建築学会 構造系論文集，No. 602，pp. 21-28，2006.4

8）今本啓一, 荒井正直 : 比表面積の観点から見た骨材の収縮特性, セメン ト・コンクリート, No.729, pp. 64-69, 2007.11

9）田中博一, 橋田浩：骨材の種類がコンクリートの乾燥収縮に及ぼす影響, コンクリート工学年次論文集, Vol. 31, No. 1, pp. 553-558, 2009.7

10) 片平博, 渡辺博志 : コンクリートの乾燥収縮率を推定するための簡易評価 指標に関する実験的検討，コンクリート工学年次論文集，Vol. 32，№.1， pp. $467-472,2010.7$

11）兵頭彦次, 井坂幸俊, 谷村充, 佐藤良一: コンクリートの乾燥収縮特性に 及ぼす粗骨材物性および収縮低減材料の影響評価, コンクリート工学年次 論文集，Vol. 32，No. 1，pp. 377-382，2010.7

12）小山田哲也, 小田島悠弥, 越谷信, 藤原忠司 : コンクリートの乾燥収縮に 対する石灰石骨材の有效性, コンクリート工学年次論文集, Vol. 32, NNo. 1 , pp. 359-364, 2010.7

13）真野孝次, 中村則清 : 砕石の品質がコンクリートの乾燥収縮に及ぼす影響 に関する実験的研究（その1２），日本建築学会大会学術講演梗概集， A-1, pp. 933-936, 2010.7

14）岸谷孝一, 馬場明生 : 建築材料の乾燥収縮機構, セメント・コンクリー ト, No. 346, pp. $30-40,1975.12$

15）慶伊富長 : 吸着, 共立全書, pp. 95-131，1965.11

16）竹内毅典, 寺西浩司, 林伸嘉, 前田大介：コンクリートの乾燥収縮に及ほ 寸各種要因の影響, 日本建築学会東海支部研究報告集, No. 42 , pp. 73-76, 2004. 2

17）日本建築学会 : 鉄筋コンクリート造建築物の収縮ひび割れ制御設計・・施工 指針（案）・同解説，pp. 190-194，2006.2

18）西岡由紀子，丸山一平：砂岩系および石灰石骨材の乾燥収縮ひずみの異方 性と線膨張係数に関する実験的研究, 日本建築学会大会学術講演梗概集, A-1, pp. 373-374, 2012, 9

19）堀口直也, 五十嵐豪, 丸山一平: 含水率の変化による骨材の体積変化に関 する基礎研究, コンクリート工学年次論文集, Vol. 33, No. 1, pp. 131-136, 2011.7

20）コンクリート技術支援機構（ASCoT）：コンクリートの収縮ひび割れ研究 委員会報告書, 2011.5

21）寺西浩司, 丸山一平, 齊藤和秀, 平岩陸, 森堅太郎：コンクリートの乾燥 収縮ひずみの推定と収縮ひび割れ対策の選定 -ASCoT「コンクリートの収 縮ひび割れ研究委員会」の成果報告-, コンクリート工学, Vol. 49, NNo. 11 , pp. 8-16, 2011. 11

(2012年 9 月 10 日原稿受理, 2013年 1 月18日採用決定) 